\title{
Notes
}

\section{Segregation Academies and State Action}

After a decade of virtually complete evasion of the school desegregation decisions, integration of primary and secondary education in the South has increased significantly. In 1965-66, 84.9 percent of black students in the eleven Southern states attended schools which were 100 percent black. In 1972-73, the figure was only 9.2 percent. ${ }^{1}$

However, in many areas of the South efforts to eliminate segregation in public education have been nullified by the massive withdrawal of white children from the public schools and the concomitant establishment of a "private" school system. This movement away from public education threatens not only the achievements of fifteen years of integration efforts but also the very legitimacy of free public education in the South. The apparent demise of metropolitan consolidation plans ${ }^{2}$ indicates that white withdrawal to segregated private schools located within an established school district may be the foremost issue in school desegregation litigation. ${ }^{3}$

This Note will examine this "segregation academy" movement and its place in the history of Southern resistance to integration. It will be argued that such academies may involve "state action," and that those which exhibit certain crucial characteristics should be judicially compelled to either desegregate or close.

\section{A Brief Legal History of the Resistance}

Though in retrospect, Brown v. Board of Education ${ }^{4}$ seems the almost inevitable culmination of a judicial trend, ${ }^{5}$ the firmness of its

1. U.S. Dep't of HEW, Press Release, Apr. 11, 1973, at 2; U.S. Commission on GiviL Rights, SOUTHERN SCHool Desegregntion 1966.67, at 7 (1967) [hereinafter cited as 1967 CRC REPORT].

2. See School Bd. v. State Bd. of Educ., Nos. 72-549, 72.550 (U.S. May 21, 1978), aff'g by an equally divided Court Bradley v. School Bd., 462 F.2d 1058 (4th Cir. 1972). The abstaining Justice in this Richmond, Va., decision was Justice Powell, whon many expect to vote against metropolitan consolidation. Cf. Wright v. Council of the City of Emporia, 407 U.S. 451, 471 (1972) (Burger, C.J., dissenting, joined by Powell, J.). See also note 29 infra.

3. See cases cited note 35 infra.

4. 347 U.S. 483 (1954), implemented, 349 U.S. 294 (1955).

5. See Mclaurin v. Oklahoma State Regents, 339 U.S. 637 (1950); Sweatt v. Paintcr, 339 U.S. 629 (1950); Sipuel v. Board of Regents, 332 U.S. 631 (1948); Missouri ex rel. Gaincs v. Canada, 305 U.S. 337 (1938). 
mandate caught supporters of segregated education without an organized response. ${ }^{6}$ Thus initial reaction to Brown was cautious and tentative; ${ }^{7}$ however, this moderation soon gave way to the fury of Southern rebellion, led by the clarion calls of Senator Harry Byrd. ${ }^{8}$

An early form of resistance were the "interposition" resolutionswhereby various Southern states purported to interpose their "sovereignty" against the Supreme Court's allegedly erroneous interpretation of the Constitution. ${ }^{9}$ These resolutions carried an implicit threat of racial violence-a threat which materialized in Mansfield, Texas, Clinton, Tennessee, and Hoxie and Little Rock, Arkansas, as mobs of angry whites attempted to prevent desegregation. ${ }^{10}$ In Little Rock, federal troops were eventually needed to curtail the revolt..11 Nevertheless, the Court, in a strongly-worded, unanimous opinion quickly ruled that threats of violence were not sufficient to slow or suspend indefinitely school desegregation. ${ }^{12}$

A more subtle approach designed to maintain segregation was devised by Senator Byrd and the other architects of Virginia's "massive resistance" strategy. ${ }^{13}$ This approach authorized the governor to close or cease funding integrated public schools. ${ }^{14}$ The federal courts, how-

6. For examples of shock and indignation during the more intense battles over integration in the South, see Faubus v. United States, 254 F.2d 797 (8th Cir.), cerl. denied, 358 U.S. 829 (1958); United States v. Wallace, 222 F. Supp. 485 (A.D. Ala. 1963); Borders v. Rippey, 184 F. Supp. 402 (N.D. Tex. 1960) (opinion of Davidson, J., on the "lojalty" of blacks); R. Coles, Children of Crisis $281-315$ (1964). Sce also R. Crain, Tue poumics of School Desegregation 237-91 (1968).

7. See R. Gates, The Miaking of Missive Resistance 28-41 (1962); A. Levis \& Tue New York Times, Portrait of a Decade 32.33 (1964); R. MicGili, Tue Soutil and tile Southerner 246-47 (1964); B. MUSE, TEN YeArs of Prelude 16-29 (1964).

8. See 102 CoNG. REc. 3948, 4004 (1956); R. Gates, supra note 7, at 13-17, 117-19; R. McGiLl, supra note 7, at 253; Southern School News, April 1956, at 1, col. 1.

9. Interposition resolutions were passed in Alabama, Florida, Georgia, Mississippi, Tennessee, and Virginia. 2 T. Exerson, D. Haber \& N. DorseN, Poutrical aNo Civil. Rights IN THE UNITED STates 1645 (3d ed. 1967). Arkansas interposed by initiative. 1 RACE REL. L. REP. 591, 1116 (1956).

These resolutions were held invalid. See Bush v. Orleans Parish School Bd., 183 F. Supp. 916, 922-26 (E.D. La. 1960), aff'd mem., 365 U.S. 569 (1961).

10. A. Lewis \& The New YoRK TIMes, supra note 7, at 10.69. B. MUUse, supra note 7, at 87-104, 122-45. See also Southern News, Oct. 1954, at 9, col. 2; id., Jan. 1956, at 9, col. 1; id., Mar. 1956, at 6, col. 1; id., Sept. 1956, at 3, col. 1; id., Oct. 1956, at 15, col. 1; id., Oct. 1957, at 1, col. 1 .

11. See Exec. Order No. 10,730, 3 C.F.R. 389 (1957); B. MIUSE, supra note 7, at 122-45; Southern School News, Oct. 1957, at 1, col 1 .

12. Cooper v. Aaron, 358 U.S. 1 (1958).

13. See generally R. Gates, supra note 7; B. MUse, Vircinia's Massive Resistance (196I).

14. See 2 T. EMerson, D. HABER \& N. Dorsen, supra note 9, at 1652.54. These laws were generally coupled with companion Iegislation repealing compulsory school attendance. Several states enacted so-called "Little Rock" laws which called for the closing of schools which were patrolled by federal troops. Id. See generally B. Surru, TuEx CLOSED Their Schools (1965); Note, School Closing Plans, 3 RACE REx. L. REp. 807 (19j8). 
ever, again struck down such laws, ordering that the schools be reopened and be supported by public funds..$^{15}$

But the school closing decisions did not completely destroy the surrogate system of private schools that had developed from, nor the concept of "private" segregation inherent in, the school closing strategy, ${ }^{10}$ and such schools continued to be important as part of the widely emulated ${ }^{17}$ plan of the Gray Commission of Virginia. ${ }^{18}$ Although the plan of the Commission was formulated in 1955, only a year after Brown, its implementation was delayed until massive resistance had failed. At that point its more moderate approach became the heart of the resistance effort. Its two-pronged program involved "pupil assignment" laws ${ }^{19}$ and massive financial aid to private segregated schools. ${ }^{20}$

The federal courts at first refused to overturn pupil assignment laws, holding that they were permissible during the early stages of desegregation. ${ }^{21}$ However, the courts soon grew suspicious of the lack of

15. See Griffin v. County School Bd., 377 U.S. 218 (1964); Hall v. St. Hclena Parish School Bd., 197 F. Supp. 649 (E.D. La. 1961), aff'd mem., 368 U.S. 515 (1962); R. SARRATT, The Ordeal of Desecrecation $312-18$ (1966).

16. The most infamous examples of private school systems arising when public schools were closed are the incidents in Little Rock, Arkansas, and Prince Edward County, Virginia. See generally B. MUSE, supra note 7, at 152-56, 187-97.

In enacting school closing laws, the Alabama, Arkansas, Georgia, and Louisiana legis. latures added companion legislation authorizing the lease or sale of public education facilities. 2 T. EMERSON, D. HABER \& N. DORSEN, supra note 9, at 1660 . Other acts per. mitted diversion of public funds to private schools, see, e.g., Nos. 4, 5, [1958] Ark. Acts 2d Extra Sess.; cf. chs. 191, 448, [1960] Va. Laws, 5 RAcE REL. L. REP. 521 (1960) (scholarships and tax credits), and the inclusion of private school teachers in public school re. tirement programs, see, e.g., No. 15, [1956] Ga. Acts, 1 RACE REL. L. RE1. 424 (1956).

Ultimately, neither school closings nor formal state legislation of bencfits was ncecs. sary to the operation of private schools. In Prince Edward County, for cxample, tuition grants and tax credits were invalidated, Allen v. County School Bd., 198 F. Supp. 497 (E.D. Va. 1961), and public schools were ordered reopened, Griffin v. County School Bd., 377 U.S. 218 (1964). Nevertheless, in 1970 the Prince Edward County School Foundation continued to enroll virtually all of the white students in the county. RACE RELATIONS INFORAATION CENTER, MAJORITY BLACK SCHOOL DisTRICTS 1 (1970) [hereinafter cited as MajortTy Black School Districts].

17. See notes 21.34 infra.

18. The Report of this commission which was formally called the Commission on Public Education, is reprinted in 1 RACE ReI. L. ReP. 241 (1955). See generally R. Gates, supra note 7, at 62.72.

19. See 1 RACE REL. L. REp. $242-43$ (1956). Under the typical pupil assignment law, a black pupil who wished to be transferred from his segregated school would apply to the local school board or a state pupil assignment board. The request was to be detcr. mined on the basis of factors such as health and aptitude of the child or availability of transportation. These laws, in thus placing the burden of desegregation on the black child, denied the existence of an affirmative duty to desegregate. By forcing individual blacks to resort to lengthy "administrative remedies" before bringing actions in federal court, see Covington v. Edwards, 165 F. Supp. 957 (M.D.N.C. 1958), aff'd, 264 F.2d 780 (4th Cir. 1959), the laws also made class actions against school boards practically im: possible. See McCoy v. Greensboro City Bd. of Educ., 179 F. Supp. 745 (M.D.N.C.), rev'd, 283 F.2d 667 (4th Cir. 1960).

20. See notes $30-33$ infra.

21. See, e.g., Carson v. Warlick, 238 F.2d 724 (4th Cir. 1956); Shuttlesworth v. Birming. ham Bd. of Educ., 162 F. Supp. 372 (N.D. Ala.), aff'd mem., 358 U.S. 101 (1958). But sec School Bd. v. Atkins, 246 F.2d 325 (4th Cir.), cert. denied, 355 U.S. 855 (1957). 
actual integration under such laws and began to hold that they were being applied unfairly to suspend desegregation.22 Southern school boards then turned, sometimes with the help of legislation, ${ }^{23}$ to socalled "freedom of choice" plans in which the discretion of parents and unofficial coercion were substituted for the artificial criteria of the pupil placement boards. ${ }^{24}$

However, again the obvious effect of such plans was to perpetuate a dual system of schools: one black, the other white, save for a few courageous and ambitious blacks. ${ }^{25}$ To counter this effect, the Court in Green v. New Kent County School Board ${ }^{20}$ held that each board had an affirmative duty to desegregate its schools and that every district had to convert to a unitary school system. Green and its progeny, Alexander ${ }^{27}$ and $S w a n n,{ }^{28}$ have had a revolutionary effect on school desegregation in the South by requiring immediate implementation of unitary plans in districts formerly proceeding at a snail's pace. These decisions thus leave no escape route from full desegregation within the geographic limits of a public school system..$^{20}$

22. See, e.g., Brown v. School Dist. No. 20, 328 F.2d 618 (4th Cir. 1964); Evers v. Jackson Municipal Separate School Dist., 328 F.2d 408 (5th Cir. 1964). The onl ${ }^{\circ}$ precise Supreme Court ruling on pupil assignment was that school boards could not give those in a racial minority in a particular school a right to transfer out of that sehool. Goss v. Board of Educ., 373 U.S. 683 (1963).

23. See, e.g., No. 117, [1956] Ala. Acts, 1 Rice Rer. L. Rer. 717 (1950); ch. 11, [1957] Tenn. Laws, 2 RAcE Rec. L. Rer. 215 (1957); Law of Alay 23, 1957, [1957] Texas Laws, 2 RAcE REL. L. REP. 693 (1957).

24. See 1967 CRC REPORT, supra note 1, at 45-46. Under such a plan the school board was supposed to approve all the requests for transfers. By placing the burden of desegregation on black children this plan achieved the same result as pupil assignment laws, while avoiding the allegation that applications were being denied on the basis of race. Thus the issue obscured in the pupil assignment litigation emerged full blown: Does the Constitution require affirmative desegregation or does it only forbid foreed segregation? See Coppedge v. Franklin County Bd. of Educ, 273 F. Supp. 289 (E.D.N.C. 1967). Cf. Weinstein, The Negro Family's Decision to Desegregate, Southern School News, Nov. 1960 , at 1 , col. 2 .

25. See 1967 CRC RePoRT 45-69, 88.

26. 391 U.S. 430 (1968), rev'g 382 F.2d 338 (4th Cir. 1967). Only the Fourth Circuit had clearly ruled favorably on freedom of choice plans, in Green and in a companion case, Bowman v. County School Bd., 382 F.2d 326 (4th Cir. 1967). The Fifth and Eighth Circuits were less willing to approve freedom of choice plans, adding a number of safeguards to school board plans and expressing skepticism about the cfficacy of frectom of choice as a means of achieving desegregation. See Unitcd States v. Jefferson County Bd. of Educ., 372 F.2d 836 (5th Cir. 1966), aff'd en bane, 380 F.2d 385 (5th Cir. 1987), cert. denied sub nom. Caddo Parish School Bd. v. Unitcd States, 389 U.S. 840 (1967); Kemp v. Beasley, 352 F.2d 14.-(8th Cir. 1965), on subsequent appeal, 389 F.2d 178 (8th Cir. 1968). See generally Note, Supreme Court, 1967 Tcrm-Equal Protection, 82 Hanv. L. REV. 111 (1968).

27. Alexander v. Holmes County Bd. of Educ, 396 U.S. 19 (1969).

28. Swann v. Charlotte-Mecklenburg Bd. of Educ., 402 U.S. 1 (1971).

29. The foremost residual problem in the post-Green era is whether the concept of affirmative duty" requires the modification of school district boundaries to maximize integration. Last term, the Court dealt with the negative side of this question by holding that it is impermissible to carve out new school districts if the effeet is to impede desegregation in the existing district by shrinking the pool of available white students. 
The other arm of the Gray Commission program was aid for private segregated schools. One type of aid, the transfer of facilities from closed public schools, ${ }^{30}$ was ended with the demise of the closing plans. ${ }^{31}$ The other form of direct state assistance, tuition grants, ${ }^{32}$ was held unconstitutional first in connection with the school closing litigation, on the theory that they were part of an overall plan to avoid Brown, ${ }^{33}$ and later as a violation of a state's affirmative duty to desegregate. ${ }^{34}$ As other forms of both overt and covert state or local assistance to segregated private schools have emerged, federal courts have gone about the business of ending such aid under the same principle that it violates the affirmative duty to desegregate. ${ }^{35}$ But despite such decisions, segregated private schools remain a significant threat to the existence of an effective system of desegregated public education in much of the South.

Wright v. Council of the City of Emporia, 407 U.S. 451 (1972); United States v. Scotland Neck City Bd. of Educ., 407 U.S. 484 (1972). The affirmative aspect of this problem, i.e., the duty to equalize racial balance through consolidation of contiguous school systems, has apparently been resolved against the duty to consolidate. See School Bd. v. State Bd. of Educ., Nos. 72.549, 72-550 (U.S. May 21, 1973), aff'g by an equally divided Court Bradley v. School Bd., 462 F.2d 1058 (4th Cir. 1972), rev'g 338 F. Supp. 67 (E.D. Va. 1972): note 2 supra. The issue will be definitely resolved when the Court hears the Detroit case. Bradley v. Milliken, 339 F. Supp. 582 (E.D. Mich. 1972), aff'd, Nos. 72-1809, 72. 1814 (6th Cir. Dec. 8, 1972), vacated and rehearing en banc ordered, Nos. 72.1809, $72-1814$ (6th Cir. Jan. 18, 1973), aff'd on rehearing, N.X. Times, June 13, 1973, at 1, col 1 . 30. See 1 Race REL. L. REP. 243-44 (1956).

31. See p. 1438 supra.

32. Tuition grant legislation was enacted in Alabama, Georgia, Louisiana, Mississippi, North Carolina, South Carolina, and Virginia. See 2 T. EMrerson, D. Haner \& N. Dorsen, supra note 9, at 1659-60; 1967 CRC REPORT 72 n.314. See generally R. GATES, supra note 7, at 67-69; King, Rebuilding the Fallen House-State Tuition Grants for Elcmentary and Secondary Education, 84 HARv. L. REv. 1057 (1971).

33. See, e.g., Lee v. Macon County Bd. of Educ., 231 F. Supp. 748 (M.D. Ala. 1964); Pettaway v. Surry County School Bd., 230 F. Supp. 480 (E.D. Va.), aff'd sub nom. Griffin v. County Bd. of Supervisors, 339 F.2d 486 (4th Cir. 1964). Cf. Hall v. St. Helena Parish School Bd., 197 F. Supp. 649 (E.D. La. 1961), aff'd mem., 368 U.S. 515 (1962); Aaron v. McKinley, 173 F. Supp. 944 (E.D. Ark.), aff'd mem. sub nom. Faubus v. Aaron, 361 U.S. 197 (1959).

34. See, e.g., Coffey v. State Educ. Fin. Comm'n, 296 F. Supp. 1389 (S.D. Miss, 1969) (tuition grants); Coffey v. State Educ. Fin. Comm'n, Civil No. 3906 (S.D. Miss. Sept. 2, 1970) (tuition loans); Griffin v. State Bd. of Educ., 296 F. Supp. 1178 (E.D. Va. 1969); Poindexter v. Louisiana Fin. Assistance Comm'n, 275 F. Supp. 833 (E.D. La. 1967), aff'd mem., 389 U.S. 571 (1968); Lee v. Macon County Bd. of Educ., 267 F. Supp. 458 (M.D. Ala.), aff'd mem. sub nom. Wallace v. United States, 389 U.S. 215 (1967).

35. See, e.g., Gilmore v. City of Montgomery, 473 F.2d 832 (5th Cir. 1973) (use of public facilities); Graves v. Walton County Bd. of Educ., 465 F.2d 887 (5th Cir. 1972) (lease of school building); Wright v. City of Brighton, 441 F.2d 447 (5th Cir.), cert. denied, 404 U.S. 915 (1971) (sale of school building); United States v. Tunica County School Dist., 323 F. Supp. 1019 (N.D. Miss. 1970), aff'd, 440 F.2d 377 (5th Cir. 1971) (salary payments to private school teachers). Cf. United States v. Mississippi, No. 72. 2521 (5th Cir. April 11, 1973); McNeal v. Tate County School Dist., 460 F.2d 568 (5th Cir. 1972) (transfers of public school buildings to private schools permitted if those schools have an open enrollment policy). But cf. Norwood v. Harrison, $310 \mathrm{~F}$. Supp. 1003 (N.D. Miss. 1972), prob. juris. noted, 409 U.S. 839 (1972) (textbook loans). 
II. Growth and Trends in the Segregation Academy Movement

\section{A. A Statistical Overview}

A small number of private segregated schools were established prior to 1966 to accommodate the moderate numbers of white children who withdrew from the public schools ${ }^{36}$ because of the token integration achieved under voluntary transfer plans. ${ }^{37}$ Real growth of the "segregation academy" movement, ${ }^{38}$ however, began when unitary school systems became required under Green's affirmative duty to desegregate. ${ }^{39}$ In the post-Green era many white parents who had previously allowed their children to attend public schools with a small number of blacks refused to enroll their children in genuinely integrated schools. The result was a massive white withdrawal from the public schools and a flurry of activity in organizing and expanding private ones. ${ }^{40}$ While direct and indirect state assistance to such schools ${ }^{41}$ was significant in facilitating their formation and maintenance, the central reason for their growth was not the availability of state support but rather the determination of white parents to avoid desegregation at any cost. ${ }^{42}$

The estimated enrollment in Southern private schools organized or expanded in response to desegregation increased from roughly 25,000 in $1966^{43}$ to approximately 535,000 by $19720^{44}$ While state-wide statis-

36. See Leeson, Private Schools for Whites Face Some Hurdles, Souminan Enuc. REP., Nov. 1967, at 13-17; Leeson, Private Schools Continue to Increase in the South, SoutribsN EDuc. REP., Nov. 1966, at 22-25; Hearings on Equal Educalional Opportunity Before the Senate Select Comm. on Equal Educational Opportunity, 9lst Cong., 2d Secs., pt. 3C, at 1502 (1970) (testimony of Melvyn Leventhal, NAACP Legal Defense Fund) [hereinafter cited as Mondale Hearings].

37. See pp. 1438-39 supra.

38. The term "segregation academy" will be used here to denote one of "a system of private schools operated on a racially segregated basis as an altcrnative abailable to white students seeking to avoid desegregated public schools." Coffey v. State Educ. Fin. Comm'n, 296 F. Supp. 1389, 1392 (S.D. Miss. 1969).

39. See pp. 1438-39 supra.

40. The recent growth of segregation academies is chronicled in a series of studies prepared for the Southern Regional Council by Katherine Griffith Terjen. See Griffith, New "Segregation Academies" are Flourishing in the South, Sourn Todst, Oct. 1969, reprinted in Mondale Hearings, supra note 36 , pt. 3D, at $1951-58$ [hereinafter cited as 1969 SRC Report, with pagination to Mondale Hearings]: Terjen, The Segregalion Academy Movement, in The SouTh ANd Her Children: Scilood Desecreation 1970.71, at 69 (Southern Regional Council, 1971) [hereinafter cited as 1971 SRC Report]; Terjen, Close-up on Segregation Academies, NEw Sourh, Fall 1972, at 50 [hercinafter cited as 1972 SRC Report].

41. See p. 1440 supra.

42. See R. Fields, The Status of Private Segregated Schools in Elevev Soutiern STAtes 3-37, and Statistical Appendix (NAACP Legal Defense Fund 1972) [hereinafter cited as LDF REPORT].

43. The figure in the text was computed from data in 1967 CRC REront, supra note 1 , at 71 .

44. 1972 SRC Report, supra note 40, at 50; for enrollments in intermediate years, sce 1971 SRC Report, supra note 40, at 69; 1969 SRC Report, supra note 40, at $1951-53$. 
tics are available, ${ }^{45}$ they do not fully show actual impact, as private school enrollment is typically concentrated in those areas where the public schools contain a majority of black children. ${ }^{46}$ Thus, although Southern private school enrollment remains below the national aver-

45. The number of private schools and students in Southern states where such in. formation is available is as follows:

\begin{tabular}{|c|c|c|c|c|c|c|}
\hline & $1967-68$ & 1968.69 & 1969.70 & 1970.71 & $1971-72$ & 1972.73 \\
\hline Ala. & $\begin{array}{c}24,513^{*} \\
191^{b}\end{array}$ & $\begin{array}{c}26,288 \\
186\end{array}$ & $\begin{array}{c}35,846 \\
295\end{array}$ & $\begin{array}{c}47,098 \\
301\end{array}$ & $\begin{array}{c}49,546 \\
302\end{array}$ & $\begin{array}{c}57,178 \\
805\end{array}$ \\
\hline Ga." & N/A & $\mathbf{N} / \mathbf{A}$ & $\begin{array}{c}34,105 \\
151\end{array}$ & $\begin{array}{c}50,078 \\
224\end{array}$ & $\begin{array}{c}68.160 \\
269\end{array}$ & $\begin{array}{c}79,414 \\
284\end{array}$ \\
\hline La. & $\begin{array}{c}143,013^{d} \\
416\end{array}$ & $\begin{array}{c}135,750 \\
398\end{array}$ & $\begin{array}{c}154,980 \\
421\end{array}$ & $\begin{array}{c}161,711 \\
456\end{array}$ & $\underset{453}{152,259}$ & $\mathrm{~N} / \mathrm{A}$ \\
\hline Miss. & $\begin{array}{c}20,598 \\
166^{\circ}\end{array}$ & $\begin{array}{c}21,951 \\
166\end{array}$ & $\begin{array}{c}42,865 \\
252\end{array}$ & $\begin{array}{c}61,530 \\
330\end{array}$ & $\begin{array}{c}62,388 \\
305\end{array}$ & $\begin{array}{c}62,396 \\
803\end{array}$ \\
\hline N. Car. & $\begin{array}{c}18,300^{\mathrm{e}} \\
\mathrm{N} / \mathrm{A}\end{array}$ & $\begin{array}{c}21,802 \\
174\end{array}$ & $\begin{array}{c}27,471 \\
201\end{array}$ & $\begin{array}{c}36,820 \\
231\end{array}$ & $\begin{array}{c}49,016 \\
257\end{array}$ & $\begin{array}{c}51,298 \\
263\end{array}$ \\
\hline S. Car. & $\begin{array}{c}24,593 \\
110\end{array}$ & $\begin{array}{c}26,887 \\
116\end{array}$ & $\begin{array}{c}26,009 \\
123\end{array}$ & $\begin{array}{c}38,762 \\
164\end{array}$ & $\begin{array}{c}40,722 \\
167\end{array}$ & $\mathrm{~N} / \Lambda$ \\
\hline Tenn. & $\begin{array}{c}35,500 \\
108\end{array}$ & $\begin{array}{c}35,691 \\
124\end{array}$ & $\begin{array}{c}35,046 \\
101\end{array}$ & $\begin{array}{c}34,947 \\
91\end{array}$ & $\begin{array}{c}42,600 \\
178\end{array}$ & $\begin{array}{c}46,000^{\circ} \\
180^{\circ}\end{array}$ \\
\hline Va. ${ }^{\circ}$ & $\mathbf{N} / \mathbf{A}$ & $\begin{array}{c}69,118 \\
322\end{array}$ & $\begin{array}{c}72,343 \\
333\end{array}$ & $\begin{array}{c}71,861 \\
348\end{array}$ & $\begin{array}{c}75,009 \\
375\end{array}$ & $\mathrm{~N} / \Lambda$ \\
\hline
\end{tabular}

- Voluntary Reporting Only

a Enrollment in nonpublic elementary and secondary schools

b Number of nonpublic schools reported by State Department of Education

c Estimated

d In Louisiana a majority of nonpublic school students attend Roman Catholic paro. chial schools. Within the total enrollment shown Catholic schools declincd from 121,509 in 1967-68 to 112,667 in 1971-72, while non-Catholic schools increased from 21,504 to 39,592. Private Schools, Schools in Transition, Aug. 1972, at 1.

e Mississippi reports the number of elementary and secondary schools separately, thus an academy with twelve grades counts as two schools.

Sources: Responses to questionnaires sent to state educational agencies, plus (1) Louisiana: Private Schools, Schools in Transition, Aug. 1972, at 1; (2) North Carolina: Charlotte News \& Observer (N.C.), Sept. 25, 1971, clipping on filc with the Yale Law Journal.

The questionnaire responses indicate that the enrollment statistics include some long. established nonsegregated private schools, see p. 1444 infra, as well as a very smail number of all black private schools, e.g., three of 200 in Mississippi in 1972.73.

There is reason to suspect that the figures given are understated. Even in Alabama, where reporting is required by state law, 35 of 65 members of the Alabama Private School Association, see note 70 infra, failed to report their 1971 enrollments to the State Board of Education. LDF REPORT, supra note 42, at 4. Florida, Texas, and Arkansas do not officially record private school enrollment. It appears, however, that the segregation academy movement is active both in Florida, see LDF REPOkT 10.12; Record at I App. 24-46, School Bd. v. Department of HEW, No. 72-3215 (5th Cir. Mar, 21, 1973) (decision of HEW hearing examiner), and in at least part of Arkansas, see LDl REPORT 8-10.

The United States Office of Education, which, as do some states, depends on voluntary reporting, recorded a nonsectarian private school enrollment increase of 242.2 percent in the twelve-state southeast region between 1961.62 and 1970-71. During the stime period, enrollment in private schools affiliated with religious denominations other than Roman Catholic increased 167.7 percent. 1972 SRC Report, supra note 40, at 50.51. By contrast, the Department of Commerce reported that nationwide private school cnroll. ment decreased 23 percent from 1965-1971. U.S. DEP'T OF COMMERCE, CURPENT PORULA'TION Report: Population Characteristics Ser. P-20, No. 234 (1972).

46. See pp. $1450-52$ infra. 
age $e^{4 \tau}$ and there is evidence that the white exodus from the public schools may have recently stabilized, ${ }^{48}$ the actual impact of the segregation academy movement in areas with a large black population is still enormous. ${ }^{48}$ It is in these areas that the force of the segregation academies must be measured and their impact on public education gauged.

\section{B. Establishment and Operation of Segregated Privale Schools}

\section{Parochial Schools}

The few children enrolled in Southern Roman Catholic schools ${ }^{50}$ are predominantly white. This de facto segregation in parochial schools is, however, due primarily to the fact that very few Southern Catholics are black. ${ }^{51}$ Since the early 1960's, the policy of the Catholic Church has proscribed racial segregation in its schools, ${ }^{52}$ but only recently has the Church taken affirmative actions to dismantle previously existing dual school systems ${ }^{53}$ and to avoid serving as a haven for segregationist non-Catholics. ${ }^{54}$

47. See 1972 SRC Report, supra note 40, at 50; Mondale Hearings, supra note 40, at pt. 3C, at $1904-09$ (statement of Senator AfcClellan). This is primarily the result of the relatively small Roman Catholic population in the South. See note 50 infro.

48. In Hinds County, Mississippi (encompassing Jackson), private school enrollment declined slightly in 1972 after substantial increases in each year since 1968. Egerton, Report Card on Southern School Desegregation, SATURDAY REview, April 1, 1972, at 41-42; Clarion-Ledger (Jackson, Miss.), Oct. 24, 1972, at 1, col. 1. Similarly, in Greenville, Mississippi, white withdrawals stabilized at forty percent of the total white student population in 1972-73 after alarming losses. See Delta Democrat-Times (Greenville, Miss.), Sept. 17, 1972, at 3, col. 1. However, stabilization short of virtually complete white withdrawal from the public schools is less common in heavily black districts. See pp. 1450-52 infra.

49. See pp. 1450.52 infra.

50. As of 1968-69, 3.8 percent of southern school-age children attended Catholic schools as compared with a 9.7 percent national average. Computed from D. GentuEn \& L. Barker, Statistics of Public and Nonplelic Elementary and Secosidary Dar Schools 1968-69, at 21, 48-51 (Department of HEW 1969).

51. Black Catholics comprise the following percentages of all Catholics in various dioceses in the South: Savannah-10 percent, Atlanta-7 percent, Nashville-3.7 pereent, Little Rock-3.4 percent, Richmond-1.9 percent. In southern Louisiana and Mlobile, how: ever, over 20 percent of Catholics are black, O'Neil, How Catholic?, Soum Todsr, Oct. 1970, at 4-5.

52. See D. ERICkson \& J. Donovan, THE Three R'S of Non-punuc EDlcation IN Louislana: Race, Region, and Reuigion 53-175 (1972); D. Lande, JiM Crow Comes to Church (1971); Guillory, Parochial Schools, South Iodsy, Dec. 1971, at 4.

53. W. Broderick, The Catholic Church aNd Black Americans in 1970, at 11-25 (US. Department of State Senior Seminar in Foreign Policy 1970); D. Enscison \& J. Dosovas, supra note 52; at 81-90, 278-84; Guillory, supra note 52. Cf. R. Crass, supra note 7, at 235-322. See also U.S. Coma'n on Civil Rights, RACial Isolation in tile Punlic Schools 38-39 (1967); Note, The Wall of Racial Isolation: The Role of Private and Parochial Schools in Racial Isolation, 43 N.Y.U.L. REv. 514 (1968).

In Louisiana black Catholic children have sought desegregation of parochial schools on the basis of the Fourteenth Amendment. See Complaint at 14-16, Greenhouse v. Greco, Civil No. 17,741-A (W.D. La., filed Apr. 3, 1972).

54. In 1971 the Diocese of Nashville announced its intent to limit the percentage of non-Catholic whites in its schools. Chattanooga Times, June 6, 1971, clipping on file 


\section{Elite Prep Schools}

Most pre-desegregation, high-quality, Southern prep schools have studiously avoided association with the segregation academy movement. The Mid-South Association of Independent Schools, to which most of these schools belong, has refused to admit segregation academies. ${ }^{55}$ Moreover, many of the members of the Association have enrolled and even recruited minority students, often providing them with substantial financial assistance..$^{58}$ Nevertheless, the non-white enrollment in such schools will probably remain relatively insignificant given the generally prohibitive tuition charges.

\section{True Segregation Academies}

The true "segregation academy" is a product of the post-Green era. ${ }^{\text {b7 }}$ These schools were at first operated with tuition grants from state

with the Yale Law Journal. Similar actions have been taken in some areas of southern Louisiana, D. ERICKson \& J. Donovan, supra note 52, at 274-78, and in Richmond, Virginia, see Bumpy Road in Richmond, TIME, Feb. 28, 1972, at 15.

55. Chattanooga Times, March 30, 1971, at 1, col. 1. The Georgia Association of Independent Schools has expelled member schools which maintain any tics with scgrcgationist school associations. LDF REPORT, supra note 42, at 16.

56. See, e.g., Mondale Hearings, supra note 40, pt. 3D, at 1986.90 (tcstimony of Dr. William B. Pressly, President of Westminster School, Atlanta, Ga.); Letter from Sally Evans, of Trinity School, Atlanta, Georgia, to authors, Mar. 24, 1972, on file with the Yale Law Journal.

57. See pp. 1441-42 supra. One may speak of three classes of segregation academy, roughly corresponding to the social and economic divisions within the white community: (a) lower-class, "rebel yell" academies; (b) white community schools; and (c) upperclass day schools.

Poor white families have organized irregular "rebel yell" academies which provide only rudimentary education. These "schools" consist of small groups of chlldren carcd for by mothers or individuals without professional educational training. Few have a permanent physical plant, and are typically conducted in private homes, churches, or abandoned commercial buildings. See Mondale Hearings, supra note 40, pt. 8D, at 1951, 1965; Brown, Academies: Many Parents Would Give Children Bad Educations, Souril TodAy, Dec. 1970, at 12; Tornquist, Rebel Yell Academies, RAMpskts, Sept. 1971, at 12. These academies have caused alarm among some state educational authoritics, who fear that thousands of white children are receiving a grossly inadcquatc cducation and will become unemployable dropouts at an early age. Georgis State Senste I'Rivate School Study Comm., Report 1-3 (1971).

By contrast, a small number of post-desegregation schools, located primarily in urban centers, offer complete academic programs, competent staffs recruited largely from the public school system, accreditation by state and regional authoritics, modern physical plants, and amenities such as guidance counseling, language and science laboratories, and airconditioning. These "segregation academies, second generation," aspirc to thic same elite status as traditional upper-class day schools in the rest of the nation. Most have announced "open enrollment" policies as required by the Internal Revenuc Scrvicc, see note 62 infra, but in practice their student bodics contain neither blacks nor low. income whites. Terjen, Private Schools, Charleston Style, Sourn TodAr, Jan.-Fcb. 1971, at 7. Examples include Jackson (Miss.) Prep., see Egerton, supra note 48, at 42; Montgomery (Ala.) Academy, see Brief for Montgomery Academy as Amicus Curiac, at 11.17, Gilmore v. City of Montgomery, 473 F.2d 832 (5th Cir. 1973); and Washington (County, 
governments. ${ }^{58}$ However, the judicial invalidation of that means of support has caused them to charge significant tuition fees, often producing financial hardship for lower- and middle-class families ${ }^{50}$ and thereby forcing reductions in local school taxes. ${ }^{00}$ The hardship would have been even greater were it not for the fact that the academies

Miss.) Day School, see Delta Democrat-Times (Greenville, Miss.), May 13, 1971, at 9, col. 3. Between these extremes are the middle-class white community schools. Although most profess to have academically-selective admissions policies, in practice no white child is refused admission solely on academic grounds. On the other hand, despite the fact that some have announced nondiscriminatory enrollment policies, there is no reported case of a black child having been admitted to a post-desegregation community academy. Tuition at white community schools ranges from $\$ 200$ to $\$ 700$ per year, with discounts for multiple enrollments from one family. 1972 SRC Report, supra note 40, at 50 ; Instant Schools, Newsweek, Jan. 26, 1970, at 59; Commercial Appeal (Memphis, Tenn.), Nov. 28,1970 , at 9 , col. 1. Tuition may be waived in the case of poor families whose children would otherwise be forced to attend desegregated public schools. Instant Sehools, supra. See generally J. Buie, An Investigation and Analysis of Selected Characteristics of Students Who Withdrew from Goldsboro City Schools System to Attend Independent Schools, Nov. 22, 1971 (unpublished dissertation, Duke University); A. Cleteland, Alabama's Private Non-Sectarian Elementary and Secondary Scliools in 1970, Dec. 9, 1970, at 51-87 (unpublished dissertation, Auburn University).

58. In Louisiana, more than $\$ 15$ million was distributed to children attending private schools. Poindexter v. Louisiana Fin. Assistance Comm'n, 275 F. Supp. 833, 858-j9 (E.D. La. 1967). Mississippi distributed over $\$ 3.2$ million. Affidavit of Armand Derfner, Coffey v. State Educ. Fin. Comm'n, Civil No. 3906 (S.D. Miss. Sept. 2, 1970). Virginia distributed more than \$I0 million. Pettaıray v. School Bd., 230 F. Supp. 480, 484 (E.D. Va.), aff'd, 399 F.2d 486 (4th Cir. 1964).

The federal courts found that the grants werc vitally important in the founding and support of many segregation academies. See, e.g., Poindexter v. Louisiana Fin. Assistance Comm'n, supra, at 845-48; Coffey v. State Educ. Finance Comm'n, 296 F. Supp. 1389, 1392.95 (S.D. Miss. 1969).

59. 1972 SRC Report, supra note 40, at 56-57; Mryles, Private Schools: Enrollments Almost Triple in Tar Heel State, Sourn Tod.x, Dec. 1971, at 5. See Mondale Hearings, supra note $40, \mathrm{pt}$. 3A, at 1198; id., pt. 3D, at 1977. Merchants in towns where segregation academies are active report declines in sales of clothing, appliances and automobiles. Id., pt. 3D, at 1947-50. Banks report increased personal borrowing to pay private school tuition, and in many families either the husband or wife has taken another job. Brown \& Provizer, The South's New Dual School System: A Case Study, New Soutil, Fall 1972, at 62. See also Biossat, Bluff on Integration Sputtering Out, Naples Daily News (Fla.), Dec. 22, 1970, clipping on file with the Yale Law Joumal. These effects have occurred despite the fact that the tuition charged by many segregation academies is only about $\$ 360$ per annum, well less than one-half of the tuition charged by reputable college preparatory schools and considerably less than the amount spent per pupil in the public schools. 1972 SRC Report 56-57. Cf. Cleveland, supra note 57, at 62.

60. Representative school tax reductions have occurred in Sumter County, Georgia, where the mill rate was cut from 20 to 12 between 1970 and 1972 , Brown \& Provizer, supra note 59, at 64-65; Western Line School District, Mississippi, which reduced its school assessment from 27 to 23.5 mills immediately after 500 white children left public schools for segregation academies, Delta Democrat-Times (Greenville, Miss.), Jan. 12, 1971, at 7, col. 1; and Calhoun District No. 2, South Carolina, which received special authority from the state legislature to reduce school taves from 35 to 25 mills and to refund previously collected taxes, MAJORTY BLACK School Distkicts, supra note 16, at 38.

School tax reductions have been disproportionate to the marginal savings caused by reduced enrollment; the cuts have therefore adversely affected the operation of public school systems. For example, Sumter County, after reducing its mill rate, ran out of funds and had to borrow one-fourth of its total $1971-72$ teacher salary costs, Brown \& Provizer, supra note 59, at 65. See generally Buic, supra note 57, at 127-35. 
have benefited from state ${ }^{01}$ and federal ${ }^{02}$ tax exemptions; the gift, lease, or purchase of public school property; ${ }^{63}$ free transportation and

61. Virtually all Southern states exempt private schools from state income taxes, property taxes, and corporate or association taxes. Some also exempt them from stiles taxes. See Questionnaires from Southern state governments, on file with the Yale Latu Journal. Louisiana has recently enacted a law which would provide for a statc income tax credit of up to $\$ 50$ for tuition paid to nonpublic schools. LA. REv. Srat. $\$ \$ 47: 85 \cdot 89$ (West Supp. 1972). Similar tax credits were invalidated in Allen v. County School Bd., 198 F. Supp. 497 (E.D. Va. 1961). But cf. Poindexter v. Louisiana Fin. Assistance Comm'n, 275 F. Supp. 833, 854 (E.D. La. 1967) (dicta).

62. The Internal Revenue Code provides that the income of charitable organizations shall be exempt from taxation, INT. REv. CODE OF 1954, § 501(c)(3), and that contri. butions to such organizations shall be deductible from the donor's net income, id. $\$ 170$ (c)(2). In 1970 black plaintiffs successfully challenged IRS approval of charitable exemptions for segregation academies in Mississippi on the ground that such exemp. tions were violative of the statutory objectives of the Code. Green $v$. Connally, 930 if. Supp. 1150 (D.D.C.), aff'd mem. sub nom. Coit v. Green, 404 U.S. 997 (1971). See 50 TEXAS L. REV. 544 (1972).

As a result of Green, the IRS has allowed tax-exempt status only to those private schools which have "racially nondiscriminatory admissions policies." IRS News Release, July 10, 1970, 7 CCH 1970 Stand. Fed. TAX Rep. I 6790, at 71,633; IRS News Relcase, July 16, 1970, 7 CCH 1970 Stand. Fed. TAx Rep. If 6814, at 71,665 .

Hundreds of racially segregated academies, however, have received favorable rulings on the basis of their own affidavits that they have an open enrollment policy. See Mindale Hearings, supra note 40 , pt. 3C, at 1714-16, 1826-28; id., pt. 3D, at 1992.2198; 1972 SKC Report, supra note 40, at 51-55; 1971 SRC Report, supra note 40, at 72.79. By September 1972 only forty-one segregated private schools had had their tax excmpt status revoked. Sixty-three other segregated private schools face revocation of their tax exempt status. LDF REPORT, supra note 42, at 38-40; Letter from Johnnic M. Walters, Commissioner of Internal Revenue, to Melvyn Leventhal, NAACP Legal Defense Fund, Jan, 9, 1973, on file with the Yale Law Journal; cf. Crenshaw County Private School Foundation v. Connally, No. 72-2775 (5th Cir. March 14, 1973).

63. See Wright v. City of Brighton, 441 F.2d 447, 451 (5th Cir.), cert. denied, 401 U.S. 915 (1971).

Examples of the transfer of school buildings and related equipment which have come to the attention of Congress, the federal courts, or the Department of Justice, include:

Alabama: Jefferson County (sale of school building for $\$ 12,500)$, Wright $v$. City of Brighton, supra, at 449

Georgia: Baker and Sumter Counties (sale of school building and equipment at bargain-basement prices, e.g., a $\$ 125,000$ school for $\$ 6,500)$, Complaint at 5.7 , Wright $v$. Baker County Bd. of Educ., Civil No. 1167 (M.D. Ga., filed March 13, 1972); Complaint at 3-4, Nelson v. Sumter County Bd. of Educ., Civil No. 730 (M.D. Ga., filcd April 22 1971). Greene County (sale of $\$ 24,000$ school for $\$ 100$ ), Mondale Hearings, supra notc 40, pt. 3D, at 2018, 2120. Walton County (lease agreement under which the board permits a private academy to use a new $\$ 289,000$ public school in exchange for the use of a former public school previously sold by the board for $\$ 17,000)$, Bricf for $A p$. pellants at 5.6. Graves v. Walton County Bd. of Educ., $465 \mathrm{~F} .2 \mathrm{~d} 887$ (5th Cir. 1972)

Louisiana: Coushatta Parish (sale of school building with equipment for $\$ 501.50$ ), Mondale Hearings, pt. 3B, at 1504 (question by Senator Mondalc). Madison Parish (rental of public high school stadium and transfer of equipment to private academy) id. at 1498 (testimony of George Strickler, Lawyers' Constitutional Defense Committce. St. Landry Parish (lease of public school building and equipment for $\$ 500$ per year) lease reprinted, $i d$. pt. $3 \mathrm{~A}$, at $1147-49$.

Mississippi: Amite County (donation of complete set of school equipment to private academy), Mondale Hearings, pt. 3B, at 1495. Smith County (private academy leased for mer public school for $\$ 5$ per year), Brief for United States at 5 . Unitcd States v. Mississippi, No. 72-2521 (5th Cir. Apr. 11, 1973). Tate County (sale of old school build. ings to segregated academies), MiNeal v. Tate County School Dist., 460 F.2d 568 (5th Gir. 1972). Leake County (bargain sale of school building), Mondale Hearings, pt. $3 B_{\text {, }}$ at 1503.

Threatened transfers of school buildings by other Mississippi school districts have been enjoined. See, e.g., Taylor v. Coahoma County School Dist., 345 F. Supp. 891 (N.D. Miss. 1972).

North Carolina: Anson County (transfer of school building to academy through in- 
state-owned textbooks; ${ }^{04}$ the use of public facilities; ${ }^{05}$ assistance from public officials; ${ }^{66}$ and support from centers of local economic power. ${ }^{.7}$ Many academies, denominating themselves "Christian Academies," are also affiliated with Protestant churches, thus obtaining the use of church buildings and additional tax-exempt revenue. ${ }^{\text {os }}$

termediary sale to volunteer fire department), Charlotte Obscrver, April 8, 1971, clipping on file with the Yale Law Journal.

South Carolina: Cherokee County (lease of $\$ 00,000$ school building for $\$ 700$ per month), lease reprinted, Mondale Hearings, pt. 3D, at 2106.

Tennessee: Fayette County (public school buildings sold or leased with school equipment included), Motion for Additional Relicf at 9, MeFerren v. County Bd. of Educ, Civil No. C-65-136 (W.D. Tenn., filed Aug. 3I, 1971).

64. Louisiana and Mississippi supply free textbooks to private school students. LA. Rev. Stat. ANN. \$\$ 17:351, 17:352 (1963); MISS. Code ANN. \$ 6658 (1952). Louisiana also supplies bus transportation, health services, and free lunches to nonpublic school students. Staff of President's Comin's on Scirool Finance, Pundic Aid to Nonpunuc EDUCATION 40 (1971). A suit challenging state provision of textbooks and other forms of aid to segregated private schools in Louisiana is pending in federal court. Brum. field v. Dodd, Civil No. 71-1316 (E.D. La., filed May 11, 1971). The Louisiana textbook law has been upheld against First Amendment challenges. Cochran v. Louisiana Statc Bd. of Educ., 281 U.S. 370 (1930).

The Mississippi free textbook law has recently been upheld by a federal court as applied to segregation academies. Norwood v. Harrison, 340 F. Supp. 1003 N.D. Miss.), prob. juris. noted, 409 U.S. 839 (1972). The cvidence in Noruood indicates that 34,000 students in 107 all-white private schools founded since 1954 were receiving state texts. 340 F. Supp. at 1011 . To facilitate the establishment of new aedemies, the Mississippi state textbook board allowed all public school children to take their texts with them when they transferred to private school. See 43 Miss. L.J. 737 n.I (1972)

65. See, e.g., Alabama: Gilmore v. City of Montgomery, 473 F.2d 832 (5th Cir. 1973) (athletic facilities).

Georgia: Complaint at 5-6, Wright v. Baker County Bd. of Educ, Civil No. 1167 (M.D. Ga., filed Mar. 13, 1972) (cafeteria facilities).

Louisiana: Motion for Judgment on the Pleadings at 1-2, Lcmon v. Bossier Parish School Bd., Civil No. 10,687 (W.D. La., filed Sept. 25, 1970) (athletic field).

Mississippi: Complaint at 3, Gooden v. Mississippi State Univ., Civil No. EC-72-12-K (N.D. Miss., filed Feb. 14, 1972) (proposed use of state university field house).

North Carolina: Myles, supra note $\mathbf{5 7}$, at $\mathbf{5}$ (city library used as academy library). Tennessee: Motion for Additional Relief at 9, McFerren v. County Bd. of Educ, Civil No. C-65-136 (W.D. Tenn., filed Aug. 31, 1971) (use of public athletic facilities).

66. Some state and local political leaders have used their public offices to facilitate the establishment of segregation academies through endorsements, fund-raising campaigns, and favorable administrative actions. Notable examples have been Alabama Governor Wallace, see Lee v. Macon County Bd. of Educ, 267 F. Supp. 4j8 (A.D. Ala.), aff'd mem. sub nom. Wallace v. United States, 389 U.S. 215 (1967); Walden \& Cleveland, The South's N'ew Segregation Academies, PuI DeLTA KAppas, Dec. 1971, at 234, 238-39; former Governor Lester Maddox of Georgia, see Mfondale Hearings, supra note 40, pt. 3D, at 1934-35, 1965; and Mississippi Senator James Eastland and State Supreme Court Justice Tom Brady, id. at 2198-2200. See Poindexter v. Louisiana Fin. Assistance Comm'n, 275 F. Supp. 833, $849-50$ (E.D. La. 1967), affd mem., 359 U.S. 571 (1968).

67. Businessmen have acquiesced in "assessments," similar in amount to public school taxes, levied and collected by segregation academies under threat of white boycott, MAjoRITY BLACX School DisTRICTs, supra note 16, at 26; B. SMITI, supra note 14, at 187; N.Y. Times, Jan. 9, 1970, at 1 , col. 4. Banks have assisted new private schools with long-term loans at favorable rates, Desegregation: The South's Tense Truce, Tus, Sept. 14, 1970, at 40; Delta Democrat-Times (Greenville, Miss.). Nov. 13, 1970, at 1, col. 5. Some labor unions have assisted the establishment of private schools for their members' children, B. MUSE, supra note 13 , at 158, and unionized workers have demanded and received bonuses from employers to pay private school tuition. Interview with Noel B. Cumbaa, Vice President, Greenville Bank, in Grecnville, Alississippi, March 26,1971 .

68. Interview with Elmo Bradley, CPA, in Greenville, Mrississippi, Mrarch 26, 1971. See 1971 SRC Report, supra note 40, at 76. One major Southern Protestant denomi- 
The segregation academies have recently joined in both state and Southern associations. The Southern Independent School Association, which is affiliated with the segregationist Citizens Councils, ${ }^{00}$ represents 396 academies with a combined enrollment of $176,0000^{70}$ State associations centralize the political influence of the academies, ${ }^{71}$ pro-

nation has, however, expressly disavowed connection with these Christian Academics. Mondale Hearings, supra note 40 , pt. 3D, at 1950 .

The numbers of students and schools involved in two Southern states are as follows:

\begin{tabular}{lcccc} 
& \multicolumn{2}{c}{ Miss.: } & $1972-73$ & \multicolumn{2}{c}{ N. Car. 1972.73 } \\
Baptist & $3,525 \dagger$ & $10+\dagger$ & $10,012 \dagger$ & $41+\dagger$ \\
Catholic & 12,529 & 50 & 10,093 & 41 \\
Sectarian Episcopal & 1,820 & 9 & 1,267 & 5 \\
Lutheran & $\ldots \ldots \ldots$. & $\ldots \ldots$. & 746 & 7 \\
Presbyterian & 1,198 & 6 & 575 & 5 \\
Seventh-Day Adventist & 145 & 2 & 998 & 18 \\
Other & 405 & 6 & 1,896 & 14 \\
Total & 19.622 & 83 & 25,587 & 181 \\
Nonsectarian* & 42,744 & 116 & 24,577 & 111 \\
Grand Total & 62,366 & 199 & 50,164 & 242
\end{tabular}

$\dagger$ Enrollment

tt Number of schools

- Includes 7 Mississippi schools with a total enrollment of 2,473, and 21 North Carolina schools with a total enrollment of 4,488 which, although unaffiliated, denominate themselves Christian Academies.

Sources: North Carolina Dep't of Public Instruction, Directory of Aptroved NonPublic Schools 1972.73 (1973); R. Thompson, Non-Public Schools 1972.73 (Miss. State Dep't of Education 1973).

69. Organized in 1954 in response to Brown, the Citizens Councils were a powerful force in massive resistance. After a decline in the 1960's, the Councils have enjoyed a recent resurgence as the promoters of segregation academies. See 1972 SRC Report, supra note 40, at 54; 1971 SRC Report, supra note 40, at 76; Minor, Mississippi's Citizcns Council Segregation Academies, Times-Picayune (New Orleans), May 17, 1970, reprinted in Mondale Hearings, supra note 40, pt. 3D, at 2198-2200; Clarion-Ledger (Jackson, Miss.), Sept. 4, 1972, at 11A, col. 1 .

70. 1972 SRC Report 54. The state organizations affiliated with SISA, according to the official journal of the Citizens Councils are:

Alabama Private School Ass'n:

Georgia (no statewide organization):

Louisiana Independent School Ass'n:

Mississippi Private School Ass'n:

North Carolina Private School Ass'n:

South Carolina Independent School Ass'n:

Virginia Independent Schools Ass'n:

Enrollment
22,000
20,000
23,000
50,000
5,000
50,000
11,000

Schools

65

56

50

92

15

70

17

Source: Southern Independent School Association Represents 176,000, Ti1E CirizeN, Dec. 1971, at 17, 18, 29.

71. The dual objectives of the private school lobby are to obtain state assistance and tax relief for private schools, while holding public school taxes and expenditures to a minimum. See Pittman, Private School Lobby is Forming, Delta Democrat-Timcs (Grectlville, Miss.), Oct. 16, 1970, at 4, col. 5; Delta Democrat-Times (Greenville, Miss.), Jatl. 26, 1973, at 6, col. 1 (private school lobby instrumental in defeating proposal for public kindergarten system in Mississippi); Majority Black Sch1ool Disrmicrs, supra note 16, at 8 (private schools lobby for educational television). 
mote interscholastic athletic competition, ${ }^{72}$ and serve as official accrediting agencies. ${ }^{73}$

The quality of instruction, staff, and physical facilities among the academies varies greatly. Quality generally increases with the size of the student body, the age of the school, and the amount of tuition charged. ${ }^{74}$ However, many academies fail to achieve even minimal standards of educational quality. ${ }^{\text {is }}$ Ferw are accredited by the regional associations of colleges and schools. ${ }^{70}$ Many are permitted to operate despite the fact that they do not meet even the lower requirements of state compulsory attendance laws. ${ }^{77}$

72. Schools lacking a first-rate athletic program are unattractive both to star athletes hoping for college scholarships and to ordinary students sceking an institution with a complete extracurricular program. See Gilmore v. City of Montgomery, 473 F.2d 832 (5th Cir. 1973). Since segregation academies as a malter of principle do not compete against desegregated public school teams, academy confercnces have been organized to promote segregated competition. MAjorit BLACK SCHIOOL DisTmats 8; Walden \& Cleveland, supra note 66 , at 238-39.

73. The South Carolina Independent Schools Association (SCISA) is recognized by the state as a private school accrediting agency, S.C. CoDE ANN. \$\$ 21-757, 21-757.2 (Supp. 1971). Private schools can still be accredited by the State Board of Education, but in practice most are accredited by SCISA. Questionnaire from South Carolina, supra note 45, at answer 4. For more information on SCISA, see 1972 SRC Report, supra note 40, at 54; 1971 SRC Report, supra note 40, at 75.77; Cleghorn, The OId South Tries Again-Segregation Academies, SATURDAY Review, MIay 16, 1970, reprinted in Mondale Hearings, supra note 40, pt. 3D, at 1963, 1967.

74. Cleveland, supra note 57, at 139-41.

75. A committee of the Georgia State Senate reported that in 1971 better than half the private schools in the state lacked "adequate facilities, library volumes, teaching aids, staff personnel, certified teaching staff, lunchroom facilities and [do not] . . . comply with safety and health standards." Grorgia State Senate Pravate School Studr Comis., REPORT 2 (1971). A study of segregation academies in Alabama found that "two-thirds of the academies currently [1971] employ one or more teachers who do not qualify for teaching certificates. Half of the schools have one or more teachers with less than the baccalaureate degree. More than two-thirds of the schools assign one or more teachers to fields of instruction other than those for which they vicre minimally prepared." Walden \& Cleveland, supra note 66, at 238 . The study also found gross inadequacies in audio-visual equipment, science laboratory equipment, instructional materials, and student counseling services at many of the schools. Id.

76. For example, only 13 of 263 non-public schools ( 4.9 percent) operating in North Carolina in $1972-73$ were accredited by the Southern Association of Colleges and Schools, and only 19 (7.2 percent) were accredited by the State Department of Public Instruction. North Carolina Dep't OF PUblic INStruction, Directory of Aprooved Non-Punlic ScHools 1972-73 (1973). In 1971-72, 35 of 453 non-public schools in Louisiana were regionally accredited. Private Schools, Schools in Transition, Aug. 1972, at 6. Cleveland's study of 25 Alabama academies showed that 5 (20 percent) vere regionally accredited and 10 ( 10 percent) met state accreditation standards. Cleveland, supra notc 57 , at 66 .

77. Of 174 North Carolina nonpublic schools in 1968-69, see note 45 supra, 62, or 35.6 percent, failed to meet low minimum standards to qualify as a school under state compulsory attendance laws. Myles, supra note 59, at 5. In 1972-73, of the 263 schools reporting to state authorities, see North Carolisa DEr'T OF PUDLic INSTRuCrion, LIST OF all Non-Public Schools in North Carolina 1972-73 (1973), 242 met the standards, North Carolina DeP't of Public Instruction, supra note 76. Thus, 21, or 8.0 percent still failed.

In 1971-72, only 148 of 453 nonpublic schools in Louisiana werc approved under state accreditation standards. Private Schools, supra note 76 , at 6 .

In Alabama, 89 percent of the school superintendents for school districts in which private schools existed during the 1969-70 school jear reported that one or more 
New academies have generally attempted to improve the quality of their academic program, ${ }^{78}$ primarily by persuading experienced public school personnel to switch to the private schools. ${ }^{70}$ However, in terms of the quality of instruction and facilities offered, most academies still remain inferior to both the white public schools which existed prior to desegregation and the presently desegregated public schools from which the whites have fled.80 It is therefore clear that the raison d'etre of the true segregation academy is racial separation, not educational excellence.

\section{Impact on the Public School System}

The availability of segregated private schools facilitates the withdrawal of both students and financial support from the public school

private schools in their districts failed to comply with minimum standards cstab. lished by compulsory attendance law. Cleveland, supra note 57, at 68 .

For an illustration of a failure to enforce attendance laws as part of a broader pattern of assistance to private schools, see Poindexter v. Louisiana Fin. Assistance Comm'n, 275 F. Supp. 833, 849-50 (E.D. La. 1967). See also 1972 SRC Report, supra note 40, at 57; Myles, supra note 59, at 5 . As a result of its repeal during massive resistance, Mis. sissippi has had no compulsory attendance law since the mid-1950's. Delta Democrat. Times (Greenville, Miss.), Jan. 9, 1973, at 5, col. 1.

78. They have apparently had some success. See, e.g., North Carolina statistics, notes 76-77 supra. From the first, the new academies have professed to offer a "better quality" education than public schools because of their racial composition, strict discipline, substantial parental control, and conservative ideology. Undoubtedly these factors of personal preference outweigh academic deficiencies and economic burdens in the minds of many white parents. See 1969 SRC Report, supra note 40, at 1951; White Citizens Councils, Welcome to Council School, reprinted in Mondale Hearings, supra note 40 , pt. 3D, at 2201-06.

79. In Louisiana, between 1962 and 1967, 35 percenit of the teachers in scgregation academies came from the public schools. Poindexter v. Louisiana Fin. Assistance Comun'n, 275 F. Supp. 833, 851 (E.D. La. 1967).

In areas in which the public schools have been almost completely resegregated, white teacher switchover has apparently been significant. Mlondale Hearings, pt. $3 \mathrm{~A}$, at 1018 . See Brief of Appellant at 4, 18, Norwood v. Harrison, No. 72-77 (U.S., dockcted July 14, 1972); Motion for Additional Relief at 9.10, McFerren v. County Bd. of Educ., Civil No. C-65-136 (W.D. Tenn., filed Aug. 31, 1971).

Teachers leave public school even though transfer to private school can mcan fi. nancial sacrifice. Myles, supra note 59 , at $\mathbf{5}$. To reduce that sacrifice, statc and local governments have occasionally assisted segregation academies by providing continued financial benefits for former public school teachers who have joincd the academies. Mississippi school districts have, for example, with the approval of the state Attorncy General, paid the salaries of white teachers who resigned to teach at academics. This tactic was enjoined and restitution ordered in United States v. Tunica County School Dist., 440 F.2d 377 (5th Cir. 1971). Georgia, Louisiana, and Virginia private school teachers are permitted to participate in state teacher retirement programs. GA. CoDE $\$ 32.2081$ (1969); LA. REv. STAT. \$ 17:600(H) (West Supp. 1973); VA. CoDE \$ 51.111.38:1 (1969). Virginia also pays a contribution into the retirement fund for the bencfit of private school teachers. Id. $\S 55.111 .38: 3$.

80. Despite widespread white fears, academic standards in desegregated public schools have not declined to the level long associated with all-black schools. In Greenville, Mississippi, for example, 1971 average achievement test scores of eleventh grade students in the public system showed an increase over 1969 scores, despite the implementation of a unitary school system and the simultaneots withdrawal of over one-third of the white students. Delta Democrat-Times (Greenville, Miss.), May 7, 1972, at 4, col. 1; id. May 8, 1972, at I, col. I. 
system. The number of whites fleeing to private schools appears to be closely correlated with the percentage of blacks enrolled in the local public schools. ${ }^{81}$ In many heavily black districts, virtually all the whites have left. ${ }^{82}$ In districts with fewer black students transfers have

81. In a study of segregation academies in Alabama, it was found that in sehool districts with a $51-75$ percent black students, an average of 21 percent of white students left to attend private schools, while in school districts with 75 percent or more black students, 53.5 percent of white students left public schools. Walden \& Cleveland, supra note 66, at 234. The 56 majority black school districts in MIississippi lost 40 percent of their white students between 1968 and 1971. Calculated from Deposition of Lloyd Henderson, Director, Education Division, Office of Civil Rights, at 1-4. Plaintifís Ex. 10, Norwood v. Harrison, 340 F. Supp. 1003 (N.D. Miss.), prob. juris. noted, 409 U.S. 839 (1972).

82. As early as 1967, the United States Civil Rights Commission reported virtually complete white flight to segregation academies in a number of majority black school districts. 1967 CRC REPORT, supra note 1 , at 76.79. Included in this phenomenon are two school districts which vere parties to the 1954 Brown decision. In Prince Edward County, Virginia, the public schools enrolled, in 1971-72, 1900 blacks and 150 whites: Prince Edward Academy enrolled the remaining 1318 whites. LDF REtonr, supra note 42, at 36-37. In May 1972 Clarendon County School Dist. No. 1 (S.C.) cnrolled 2195 blacks and 5 whites; 411 whites attended Clarendon Hall Academy. Id. at 31-32.

The implementation of unitary school plans after 1969 resuled in similar white withdrawals in Mississippi's heavily black districts:

\section{District}

Canton Munic.

Hollandale Mfunic."

Holmes County ${ }^{2}$

Indianola Munic.

Tunica County

Wilkinson County

\begin{tabular}{rlrl} 
Fall & $1969^{2}$ & \multicolumn{2}{c}{ Feb.19702 } \\
W.* & B.† & W. & B. \\
1,314 & 3,746 & 36 & 3,717 \\
155 & 2,000 & 0 & N/A \\
904 & $5,657+\dagger$ & 0 & N/A \\
991 & 2,799 & 0 & 2,757 \\
428 & 3,039 & 0 & N/A \\
766 & 2,709 & 0 & 2,693
\end{tabular}

Fall 19723

IV. $B$.

$186 \quad 3,746$

$22 \quad 1,942$

85,071

$304 \quad 3,077$

812,836

$52 \quad 2,471$

* White public school enrollment

$\dagger$ Black public school enrollment

It Fall, 1968

1 These columns are, unless otherwise indicated, taken from the depositions of the superintendents of schools of the various districts named, all filed in Coffey $v$. State Educ. Fin. Comm'n, Civil No. 3906 (S.D. Miss., filed March 17, 1970); Deposition of D. B. Floyd, Superintendent of Indianola Munic. School Dist., at 5.6; Deposition of L. Fortenberry, Superintendent of Canton Munic. School Dist, at 4-5; Deposition of G. Pettey, Superintendent of Tunica County School Dist., at 5-7; Deposition of B. Waites. Superintendent of WVilkinson County School Dist., at $\mathbf{5} \cdot 6$.

Fall 1970 and all Holmes County statistics are compiled from data in Deposition of Lloyd Henderson, Director, Education Division, Office of Civil Rights, at 1-4, Plain. tiff's Ex. 10, Norwood v. Harrison, 340 F. Supp. 1003 (N.D. Miss.), prob. juris. noted, 409 U.S. 839 (1972).

3 In this column, statistics for Canton Municipal, Holmes County, and Wilkinson County School Districts are taken from the Fall 1972, Compliance Reports at 1, filed by each of those districts in United States v. Hinds County School Bd. Nos. 28030, 28042 (5th Cir., filed Dec. 1972); statistics for Indianola Alunicipal School District are taken from Fall 1972, Compliance Report, at 1, United States v. Indianola Separate Municipal School Dist, Civil No. GC-6637-K (N.D. Miss., filed March 1973); statistics for Tunica County are taken from Fall 1972, Compliance Report, at 1, United States v. Tunica County School Dist, Civil No. DC-6718-K (N.D. Afiss., filed March 1973): statistics for Hollandale Municipal are taken from Fall 1972, Compliance Report, at 1. United States v. Hollandale Munic. School Dist, Civil No. GC-6922-S (N.D. Aliss., filed Sept. 1972).

Hollandale statistics for 1969 and Feb. 1970 are from MIAJorrry BLACr Sarool Districts, supra note 16 , at 24. 
been less dramatic. Nevertheless, the transfer rate is often sufficient to produce a significant change in the district's racial composition. ${ }^{83}$ Often the withdrawals have resulted in a failure to eliminate all-black public schools. ${ }^{84}$ Achieving desegregation where the white student population has thus been depleted requires increasingly drastic means, notably more busing. Such measures are predictably self-defeating, since they in turn accelerate the exodus of white pupils. ${ }^{85}$

A second effect of this white withdrawal is the undermining of financial support for the public schools. Decreased enrollment results in an automatic reduction of state funds for local systems.80 Moreover, state legislatures and local school boards have also often reduced

83. Three school districts illustrate the impact of student withdrawal on public school desegregation plans in contexts which are, respectively, rural, urban, and mctro. politan.

Pointe Coupee, a rural parish in central Louisiana, instituted a school pairing plan in 1969-70. Within one year the white enrollment in parish schools decreased by more than 70 percent; the concentration of black students increased from 60 to 85 percent. Although the school board made modifications in the pairing plan, persuading sume white students to return, parish schools are still 70 percent black. Brief for Appellces at 2-4, Boyd v. Point Coupee Parish School Bd., No. $71-3305$ (5th Cir., filed Oct. 19, 1971).

In Jackson, Mississippi, white student enrollment in September 1970 was 42 percent below that of a year earlier, following a January 1970 order to convert to a unitary system. As a result of white flight, eight public schools remain more than 90 percent black and seventeen are more than 75 percent black. Compliance Reports, Singleton v. Jackson Munic. Separate School Dist., Civil No. 3379 (S.D. Miss. 1971); Brief for Ap. pellant at 16-17, Norwood v. Harrison, No. 72-77 (U.S., docketed July 14, 1972).

By February 1973, Memphis, Tennessee, the nation's tenth largest school district, had lost nearly a quarter of its 1971-72 white enrollment of 67,500 . The major triggering event was the January 1973 implementation of a desegregation plan requiring inten. sive busing of over 13,000 students. A substantial proportion of these pupils have cn. rolled in existing private schools or in eighteen new academies established by the Citizens Against Bussing. See Northcross v. Memphis Bd. of Educ., 341 F. Supp. 588, 586 (W.D. Tenn.), aff'd, 466 F.2d 890, $892-93$ (6th Cir. 1972), cert. denied, 4i U.S.L.W. B445 (Feb. 20, 1973); Commercial Appeal (Memphis, Tenn.), Jan. 7, 1978, at 81A, col. 3; id., Feb. $18,1973, \$ 6$, at 2 , col. 3 .

84. The experience of Jackson, Mississippi, is illustrative. See note 83 supra.

85. See Wright v. Council of the City of Emporia, 407 U.S. 451, 464 (1972); Boyd v. Pointe Coupee Parish School Bd., 332 F. Supp. 994 (E.D. La. 1971), appeal docketed, No. 71-3305, 5th Cir., Nov. 17, 1971.

86. In most southern states, state aid to local school districts is based on attendance. See, e.g., Ala. CODE tit. 52, § 207(2) (Supp. 1971); GA. CODE ANN. cl. 32.6 (1969); Miss. CODE ANN. $\$ \$ 6248-01$ to $6248-26$ (Supp. 1972). Although reductions in statc funding are based on declining enrollment, a school system cannot reduce cxpenditures in direct proportion to lower enrollment since overhead costs established on the basis of the higher attendance cannot be immediately reduccd. Buie, supra note 57, at 128.30; Interview with W. B. Thompson, Greenville Superintendent of Schools, in Grecnville, Mis. sissippi, March 26, 1971 .

Emergency School Assistance Funds, Pub. L. No. 91-380, 84 Stat, 800, provide limited federal grants to improve the quality of recently desegregated schools. These funds, however, cannot be used to replace funding from other sources which have becn re. duced as a result of desegregation. 45 C.F.R. $\$ 181.6$ (1972). These funds also cannot be given to school districts which have engaged in transfers of public school property to private schools. 84 Stat. 800; 45 C.F.R. $\$ 181.3($ a)(4) (1972). A survey of 295 school districts in the South indicated that 52 have engaged in such transfers. AMEktcAN Friends Service Comm., The Emiergency School Assistance Act: An Evaluntion 40, 57, 99-100 (1970). ESAP funds have been terminated in Fort Lauderdale, Florida, Isle of Wight County, Virginia, and Charlotte-Mecklenburg, North Carolina. See Record at I App. 44, School Bd. v. Department of HEW, No. 72-315 (5th Cir. Mar. 21, 1973). 
discretionary educational appropriations. ${ }^{8 \tau}$ Similarly, local electorates have increasingly refused to approve new bond issues, and issues approved before desegregation have not been funded. ${ }^{88}$

Nonmonetary resources have also been diverted from the public schools. Transfers of school buildings and equipment to the private academies have affected operations in some districts. ${ }^{80}$ Transfers of experienced teachers and administrators have also occurred in virtually every district where academies are active. ${ }^{00}$ This in turn accelerates withdrawals, since white parents are often reluctant to enroll their children in classes taught by blacks. ${ }^{.1}$

It is thus evident that the segregation academies are a key element in a new dual system of schools-one, white and "private"; the other, disproportionately black and "public." The academies clearly threaten to frustrate the national goal of banishing racial segregation from the classroom.

\section{Segregation Academies and State Action}

Before the courts can move directly against the segregation academies, they must find the Fourteenth Amendment applicable to those privately organized and operated schools. However, since the early Civil Rights Cases, ${ }^{92}$ it has been settled that the Fourteenth Amend-

87. Typical reductions of school taxes and expenditures in local districts are discussed note 60 supra. Reduced expenditures for public education have been most evident in predominantly black public school systems which remain in the control of white school boards. See, e.g., Complaint at 3-4, Nclson v. Sumter County Bd. of Educ, Civil No. 730 (M.D. Ga., filed April 22, 1971). Reductions of state aid to public schools have not been evident probably because private school forces are not as coneentrated at the state level as they are in some local school districts. However, proposed increases in state appropriations for education, particularly for teachers' salaries, have been resisted and curtailed by private school lobbies. See MAJORTY BLAck Scioor Distmacts, supra note 16 , at $6-8$.

88. See, e.g., United States v. Hinds County School Bd., 433 F.2d 605, 609 (5th Cir. 1970); Franklin v. Quitman County Bd. of Educ., 288 F. Supp. 509 (N.D. Miss. 1968); Majorimy Black School Districts 8.

89. See note 63 supra. However, at least some of the buildings transferred had become obsolete or surplus due to school consolidation prior to desegregation. See McNeal v. Tate County School Dist., 460 F.2d 568 (5th Cir. 1972): United States v. Mississippi, Civil No. 4706 (S.D. Miss. May 3, 1972), remanded, No. 72-2521 (J̈th Cir. Apr. $11,1973)$.

90. See note 79 supra.

91. Faculty resignations in Pointe Coupee Parish, Louisiana, are representative of those in many districts. Prior to the 1969-70 school pairing plan, the Parish cmployed 147 black and 120 white teachers. In that year fifty-three white teachers resigned. Although its -desegregation plan required faculties to be distributed among schools on a racially balanced basis, see Singleton v. Jackson Munic. Separate School Dist., 419 F.2d 1211, $1217-18$ (5th Cir. 1969), cert. denied, 396 U.S. 1032 (1970), the faculties at three historically black schools following the white resignations consisted of seven whites and sixty-seven blacks, while faculties at three formerly white schools viere composed of thirty-nine whites and twenty-two blacks. Brief of Appellee at 2, Boyd v. Pointe Coupee Parish School Bd., No. $71-3305$ (5th Cir., filed Oct. 29, 1971). See also note 83 supra.

92. 109 U.S. 3 (1883). See also United States v. Cruikshank, 92 U.S. 542 (1875). 
ment applies only to actions of the "state" and not to actions which are "private." 93 At one extreme-the official actions of all state and local governing agencies-there is no doubt that the Amendment applies. ${ }^{94}$ At the other extreme, there are actions which are undeniably those of private individuals. ${ }^{95}$

However, between these two clear cases $^{00}$ there are a multitude of situations in which the state is somehow involved in the activity of a private group ${ }^{07}$ or in which a private group exercises what might be called governmental authority. ${ }^{08}$ Generally, the Supreme Court has held that the distinction between individual and state action depends on whether the state has become "substantially involved" 00 in a nominally private discrimination. The content of "substantially involved" shifts from situation to situation, but basically the phrase invokes an ad hoc balancing of the effect of the discrimination on one side, and the freedoms of association and privacy on the other. ${ }^{100}$

In the case of segregation academies there is, as discussed above, evidence of state or local involvement both in the provision of equipment, buildings, and teachers, and in the state's failure to protect the public schools from the impact of the private academies. Whether the academies in a particular community are state action thus involves both a consideration of such involvement and an ad hoc balancing of the associational interests inherent in private education and the effect of the discrimination.

But despite the Court's willingness to express state action tests in terms of substantial state involvement, other decisions suggest that the opponents of the segregation academies would be well advised to convince the Court that the state action involved satisfies an even more demanding definition. This is the proposition that it is im-

93. The literature on the question of state action is enormous. See, c.g., Black, Foreword: State Action, Equal Protection, and California's Proposition 14, 81 HAnv. L. REv. 69 (1967); Henkin, Shelley v. Kraemer: Notes for a Revised Opinion, 110 U. PA. L. REv. 473 (1962); Peters, Civil Rights and State Non-Action, 34 Notre DAME LAw. 908 (1959); Silard, A Constitutional Forecast: Demise of the "State Action" Limit on the Equal Protection Guarantee, 66 CoLUM. L. REv, 855 (1966).

94. See Watson v. City of Memphis, 373 U.S. 526 (1963); Holmes v. City of Atlanta, 350 U.S. 879 (1955).

95. See Moose Lodge No. 107 v. Irvis, 407 U.S. 163 (1972); Adickes v. S. H. Kress Co., 398 U.S. 144 (1970).

96. These two clear cases are posited by Justice Harlan in Adickes v. S. H. Kress Co., 398 U.S. 144, 169 (1970).

97. See, e.g., Moose Lodge No. 107 v. Irvis, 407 U.S. 163 (1972); Burton v. Wilming* ton Parking Authority, 365 U.S. 715 (1961).

98. See, e.g., Evans v. Newton, 382 U.S. 296 (1966); Terry v. Adams, 345 U.S. 461 (1958).

99. See Moose Lodge No. 107 v. Irvis, 407 U.S. 163 (1972); Reitman v. Mulkcy, 389 U.S. 369 (1967); Burton v. Wilmington Parking Authority, 365 U.S. 715 (1961).

100. Compare Moose Lodge No. 107 v. Irvis, 407 U.S. 163 (1972), with Reitman v. Mulkey, 389 U.S. 369 (1967). 
permissible for the state to avoid the constitutional standards applied to its functions by permitting those duties to be assumed by nominally private groups. Thus, in Terry $v$. Adams ${ }^{101}$ the Court held a private political club to Fifteenth Amendment standards after finding that it had effectively controlled Democratic party primaries in Texas since 1890. The state had been ordered to desegregate the official primary, ${ }^{102}$ and the Court found that the club had "produce[d] the equivalent of the prohibited [official Democratic primary] election."103

A similar principle was employed in the more recent case of Evans v. Newton. ${ }^{104}$ There the Court found "state action" where a city had operated a park under the terms of a will mandating racial segregation, even after the city had resigned in favor of private trustees. ${ }^{105}$ This principle that a state or local governing agency may not avoid the constitutional requirements attached to its functions by yielding them to a nominally private group finds further support in other "state action" holdings. ${ }^{106}$

This approach seems persuasive in the case of segregation academies. Ostensibly private groups which assume from the state the function of providing education take that function with its constitutional burden: They too must provide education on a desegregated basis. Indeed, the Supreme Court intimated as much when it held that the closing of public schools in order to avoid desegregation and the concomitant establishment of segregated private schools was state action violative of the Fourteenth Amendment. ${ }^{107}$

101. 345 U.S. 461 (1953).

102. Smith v. Allwright, 321 U.S. 649 (1941).

103. 345 U.S. at 469 .

104. 382 U.S. 296 (1966). See also Pennsylvania v. Brown, 392 F.2d 120 (3d Cir.), cert. denied, 391 U.S. 921 (1968); Hampton v. City of Jackisonville, 304 F.2d 320 (Fut Cir. 1962), cert. denied, 37 I U.S. 111 (1963).

105. It appears from Justice Douglas opinion that the city resigned when suit was brought in state court to remove it as trustee because the city had begun to admit blacks to the park. See 382 U.S. at 297-98. The state court accepted the city's resignation and appointed three private trustees.

Later the Court allowed the Georgia courts to permit the park to revert to the donor's heirs. Evans v. Abney, 396 U.S. 435 (1970).

106. See Reitman v. Mulkey, 387 U.S. 369, 374-75 (1967) (state constitutional amendment that displaces state fair housing laws is state action violative of Fourteenth Amendment); Burton v. Wilmington Parking Authority, 365 U.S. 715, 724-26 (1961) (state agency leases part of public building to private restaurant which discriminates on the basis of race; held: lessee must recognize fourteenth Amendment commands "as though they were binding covenants written into the agreement itselr"). See also Local 590 . Amalgamated Food Employees v. Logan Valley Plaz, Inc., 391 U.S. 303 (1968): Silver v. New York Stock Exchange, 373 U.S. 341 (1963); International Ass'n of MIachinists y. Street, 367 U.S. 740 (1961); Marsh v. Alabama, 326 U.S. 501 (1946); Stecle v. Louisville \& N. R.R., 323 U.S. 192 (1944); Lavoi v. Bigwood, 457 F.2d 7 (lst Cir. 1972).

107. See Griffin v. County School Bd., 37T U.S. 218, 232 (1964). The Court noted that the racial objective of the school closing was its constitutional defect: "Whatever non-racial grounds might support a State's allowing a county to abandon public schools, the object must be a constitutional one, and grounds of race and opposition to desegregation do not qualify as constitutional." Id. at 231. 
The difficulty with this principle is thus not conceptual, but rather evidentiary. As indicated by language commonly used in the cases, the Court is very sensitive to the problem of proof in state action litigation. Thus, a finding of state action requires "sifting facts and weighing circumstances." 108 It is therefore necessary to define those facts which are probative of either the delegation to or assumption by private groups of the former state function of providing segregated education.

\section{Toward Judicial Action Against Segregation Academies}

\section{A. The Indicia of State Action}

The first element in a finding that segregation academies represent state action is the preexistence of a dual system of public schools. ${ }^{100}$ The second factor is some event, normally a desegregation order, which makes it difficult or impossible to maintain this discriminatory system. If, after this event, a system of white private schools is created to replace "white" public schools, that system is the product of state action, and corrective judicial action is appropriate. The act of replacement involves private groups assuming a function formerly exercised by the state at the time the state is under a constitutional command in regard to that function.

In looking for such a replacement, the threshold inquiry is whether there are substantial increases in white private school enrollment following public school desegregation. In this initial determination, the growth of private school enrollment would be compared with the rate of growth preceding the desegregation order. A noticeable acceleration correlated with a disproportionately white withdrawal would alert a court to the possibility that private schools were being used to circumvent the duty to desegregate. ${ }^{110}$ It would then be necessary to determine whether the increase in private school enrollment were properly characterized as state or private action. The experience of the

108. Burton v. Wilmington Parking Authority, 365 U.S. 715, 722 (1961).

109. This element would also exist in the North should it be held that racial balance and metropolitan consolidation are required to eliminate the de facto scgregation of Northern school districts. See Adams v. Richardson, 41 U.S.L.W. 2452 (D.D.C. Feb. 16, 1973).

110. Even if an explanation other than a community desire to avoid desegregation could be shown to account for the coincidence of the desegregation order and the trans. fers from public to private schools, if the effect is that private groups have assumed the government's educational function, the schools are subject to the Fourtecnth Amendment command represented by the desegregation order. Cf. Reitman v. Mulkey, 387 U.S. 369 (1967); Griffin v. County School Bd., 377 U.S. 218, 231 (1964); Terry v. Adams, 345 U.S. 461, 466 (1953). See p. 1455 supra. 
South is useful in suggesting the characteristics of a rapid shift from publicly to privately segregated education. Because these factors, which determine whether the academies represent state or merely private action, appear in the flux following the judicial order, they may not be subject to precise measurement. They should, however, be susceptible of sufficiently accurate description to provide a basis for judicial remedies.

The first of these factors is the extent of white student transfer, in both absolute and proportional terms. Should the transfer be insignificant, this would be evidence that it is merely the product of private action. If, however, virtually all of the white students in a particular community flee the public schools to enroll in private schools, more than individual choice is obviously involved. Such a massive uniform action necessarily implies that the state's educational function has been transferred to the private schools. This fact, in itself, is virtually conclusive evidence that the transfer, and the private schools benefited by it, exhibit state action. ${ }^{111}$

Between the extremes of de minimis and total withdrawal, the flight of white students is inconclusive on the issue of state action. Other factors, such as the various supportive functions that the community provides for the education of its children, must be considered before the private schools can be regarded as state action.

The first of these other factors is the transfer, by purchase or gift, of public school property to segregated private schools. ${ }^{112}$ If a substantial amount of equipment has been transferred, it would seem that more than individual dereliction is involved. Either by participation or acquiescence, the state is providing necessary support to the private schools with equipment purchased by public funds.

The second factor is the shifting of white teachers and administrators from public to private schools.133 Again, state rather than individual action is evident if such transfers occur en masse, involve the recruitment of students, or proceed more rapidly than the rate of student withdrawal. Again, either by participation or acquiescence, the

111. Note that transfers of this magnitude will have the effect of producing a racial composition in the public schools which is "substantially disproportionate" to that of the school age community including the transferred students. Cf. Swann v. CharlotteMecklenburg Bd. of Educ., 402 U.S. 1, 26 (1971). It may, thus, be appropriatc in determining whether the transfer is sufficient to justify judicial interiention to determine whether it has produced a substantial racial disproportion in the public schools.

112. See note 63 supra. This factor is active primarily during the period of private school formation. Of the several factors to be presented, only that of private school financing, see p. 1458 infra, is likely to remain active in a stabilized post-withdratial period.

113. See note 79 supra. 
state is providing private schools with a public asset-teachers and administrators who had gained popularity, experience, and the confidence of the community by their tenure in the public schools.

The third factor concerns educational funding, and has two elements: decreases in funding for public schools and the means employed in paying for private schools. If public school funding is reduced in an amount substantially greater than the actual decrease in the cost of integrated public education caused by the withdrawal of the white students, this fact is evidence of state action in shifting resources away from the public schools. ${ }^{114}$ Similarly, if the private schools are supported by what is in essence an informal system of taxation, ${ }^{115}$ a public subsidy to private education again exists. Where disproportionate decreases in public school financing exist in conjunction with such an informal tax system, there is an especially strong case that there has been a shift of financial resources for the purpose of continuing segregated education-a shift which again involves the state.

The fourth factor is probably the most difficult to measure. It involves community support of private, segregated education by organizations such as labor unions and social clubs. Activity by these groups against public education and in favor of private education, especially when encouraged by local public officials, is again evidence of state action.116

Ultimately, the determination of whether the segregated private schools within a particular community constitute state or individual action will require that a court weigh such factors in light of its experience with the desegregation history of the community. Whether this factual determination is easy or difficult in a given case, the legal standards are clear: Segregated private schools to which the state's constitutionally burdened educational function has been transferred represent state action to continue racial segregation. ${ }^{117}$

114. The projected cost of integrated education as a standard for measurement is to be distinguished from the cost of formerly segregated education for whites. That is to say, the proper test for reductions in public school budgets is not the amount spent on the education of white students in a segregated system.

115. An informal system of taxation could include such examples as assessments of businesses, high pressure fund-raising campaigns, illegal tuition grant payments made by state governments, see note 58 supra, and discounts allowed poorer families who cannot afford segregation academy tuition. See note 57 supra.

116. See note 66 supra.

117. While the "state action" characterization may normally be expected to arise from the activities of a certain group of schools, other schools, which do not participate in the patterns of action which are factors identifying state action, are not tainted. How. ever, this principle of nonparticipation is easier to state than to reduce to concrete examples. Since probably all private schools in the South have benefited to some extent from the white exodus from public schools, the test to be applied is necessarily relative. 


\section{B. Remedies}

Once it is determined that certain segregated private schools are the product of state action, they are properly subject to desegregation orders, just as are the public schools. ${ }^{118}$ of course, private schools unwilling to integrate would have the alternative of closing. If desegregation of a particular academy is not speedily achieved, the court should interpret that inaction as an election on the part of the school to close. ${ }^{119}$

Whether the academies would be properly held subject to other Fourteenth Amendment duties-such as the prohibition on school prayer-would depend on the circumstances of the particular case. For the purpose of reaching racial discrimination, courts are justified in finding state action on facts which might not be state action for the purpose of imposing less compelling duties. ${ }^{120}$

In opposition to the forced desegregation of private schools, one might argue that Supreme Court decisions enunciating the right of parents to direct the education of their own children forbid such a harsh remedy. ${ }^{121}$ However, in overturning the freedom of choice plans, the Court by implication held that, in the area of public education, the state cannot permit parents' racially motivated choices. ${ }^{122}$ Since the analysis proposed here allows the forced desegregation of academies

118. Desegregation is appropriate in view of the probability that the lesser alternative of requiring an open enrollment policy would not correct the racially identifiable nature of the academies any more than freedom of choice plans did in the case of public schools. See Green v. County School Bd., 391 U.S. 431 (1968). Aloreover, for tax reasons, many academies already have nominal open cnrollment policies. Sce note 62 supra.

Those cases which have debated the question of open enrollment have not involved an argument that the private schools constituted state action. Sec Gilmore v. City of Montgomery, 473 F.2d 832 (5th Cir. 1973); cf. United States v. Mississippi, No. 72.2521 (5th Cir. Apr. 11, 1973); MfNeal v. Tate County School Dist., 460 F2d 568 (jth Cir. 1972).

Desegregation of a private school was requested in Complaint at 2, Reed v. Pillow Academy, Civil No. GC 70-79-K (N.D. Miss., filed Oct. 9, 1970). This action was dismissed at plaintiff's request on February 5, 1971. Delta Democrat-Times (Greenville, Miss.), Feb. 5, 1971, clipping on file with the Yale Law Joumal.

119. It seems likely that segregation academies will close rather than integrate. Cf. Palmer v. Thompson, 403 U.S. 217 (1971); Evans v. Abney. 396 U.S. 435 (1970).

A finding of state action also would support an award of damages under 42 U.S.C. $\S 1983$ (1970). See Adickes v. S.H. Kress Co., 398 U.S. I14 (1970); Kerr v. Enoch Pratt Free Library, 149 F.2d 212 (4th Cir. 1945). Assessing heavy damages against segregation academies will most likely force those academies to close. Cf. notes 57.61 supra.

120. See Powe v. Miles, 407 F.2d 73, 81 (2d Cir. 1969): H. Friesdry, TuE D.artaouti! College Case and the Public-Private Penumbra 27-31 (1969).

121. See Wisconsin v. Yoder, 406 U.S. 205 (1972); Pierce v. Society of Sisters, 263 U.S. 510 (1925); Meyer v. Nebraska, 262 U.S. 390 (1922); Note, supra note 53, at 525.34.

The right of parental control of upbringing is not absolute. Private schools are subject to reasonable state regulation. See $R$. CAxpreld, L. Cunnincius \& R. McPue, The Organization and CoNtrol of AMgrican Schools 494.97 (1965). See also Elson, State Regulation of Nonpublic Schools, in Punlic Controls for Nonpuncic Scrioots 104 (D. Erickson ed. 1969).

122. Green v. County School Bd., 391 U.S. 431 (1968). See p. 1439 supra. 
only when state action has been found, this principle of the freedom of choice decisions should control. Arguments that forced desegregation of church-affiliated academies would impair the "free exercise of religion" are similarly without merit. ${ }^{123}$

There are also other less drastic remedies, based on the broad powers of the federal courts in implementing desegregation, ${ }^{124}$ which could be invoked against specific conditions created by the segregation academy movement in a particular community. These remedies do not require that the operation of academies be found state action in the sense previously discussed. But even where that state action is found, the court could, as a matter of discretion, employ these specific remedies rather than order desegregation. They should be invoked, however, only when there is reason to believe that they will succeed in removing the state action taint.

The first of these lesser remedies is to enjoin direct or indirect state support, including the transfer of public school property to segregated private schools. Federal courts have already employed this remedy to halt the transfer of public school property. ${ }^{125}$ An order for the restitution of the property would seem appropriate, although it does not appear to have been employed in any cases. ${ }^{126}$

In order to counteract reductions in the financial support of public education, the court could require local school officials to raise more money for public schools, hire sufficient personnel, or provide adequate equipment. The Supreme Court has already approved a similar remedy in the context of the school closing litigation. ${ }^{127}$ There are, of course, obvious limits to this remedy: Courts are poorly equipped to oversee public school budgets; and it is unlikely that school board

123. Courts have repeatedly held that religious practices inimical to the public welfare may be regulated or prohibited. See, e.g., Reynolds v. United States, 98 U.S. 145 (1878) (polygamy); Lawson v. Commonwealth, 164 S.W.2d 972 (Ky. 1942) (usc of poisonous snakes). Cf. Braunfield v. Brown, 366 U.S. 599 (1961) (prohibition of retail sales on Sunday does not interfere with free exercise of Jewish religion).

The "right of association," see Emerson, Freedom of Association and Freedom of Expression, 74 YALE L.J. 1 (1964), of course, cannot protect racial discrimination by those "associations" which are found to involve state action. Cf. International Ass'n of Machinists v. Street, 367 U.S. 740 (1961).

124. Swann v. Charlotte-Mecklenburg Bd. of Educ., 402 U.S. 1, 17 (1971).

125. See Graves v. Walton County Bd. of Educ., 465 F.2d 887 (5th Cir. 1972); McNcal v. Tate County School Dist., 460 F.2d 568 (5th Cir. 1972); Wright v. City of Brighton, 441 F.2d 447 (5th Cir. 1971). See also Complaint at 10, Brumfield v. Dodd, Civil No. 71-1316 (E.D. La., filed May 11, 1971) (seeking general order prohibiting any kind of state aid to segregation academies).

126. Such an order was approved by implication when the Fifth Circuit ordered a local school board to recover certain illegal payments to segregated private schools or be held personally liable therefor. United States v. Tunica County School Dist., 323 F. Supp. 1019 (N.D. Miss. 1970), aff'd, 440 F.2d 377 (5th Cir. 1971).

127. See Griffin v. County School Bd., 377 U.S. 218, 233 (1964). 
members would be sent to jail for contempt, should the community refuse to pay school taxes or consistently defeat bond issues.

Organized fund-raising and managerial efforts by those maintaining private schools may also constitute a threat to the success of desegregation. If so, an order to halt the interference would be appropriate. Actions enjoinable would include fund-raising campaigns, construction or purchase of buildings for new academies, and any activity designed to create pressure on white parents or children to attend private school.12s Again, widespread resistance to desegregation probably could not be controlled by injunction; and overuse of the injunction could cause serious political reactions. ${ }^{129}$

Finally, where there is discernible involvement of public officials, actions could be brought under traditional concepts of state action to enjoin those officials and private school supporters from conspiring to deprive public school children of their civil rights. ${ }^{130}$ If appropriate, damages could also be assessed.

\section{Conclusion}

In Brown the Court declared that racially separate schools were "inherently unequal." Subsequently it held that communities could not use "ingenious or ingenuous schemes" to thwart this principle. ${ }^{131}$ Yet in some school districts today, desegregation has been largely thwarted by the organization of a system of white private schools to replace white public schools. Such tactics are not, however, beyond judicial reach, and should be halted by application of the Fourteenth Amendment to this new, but equally unconstitutional, dual system of schools.

128. Such noninterference commands are typically coupled as a matter of course with desegregation orders. See, e.g., United States v. Kaspar, 2 RACE REL. L. REP. 795, 801 (E.D. Tenn. 1957) (charge to jury in contempt trial of individual who violated an order to cease interfering with desegregation efforts). See also Lee $v$. Mracon County Bd. of Educ., 231 F. Supp. 743, 755 (M.D. Ala. 1964).

129. Cf. F. Frankfurter \& N. Greene, The Lador Injunction (1932).

130. 42 U.S.C. $\$ \S 1983,1985$ (1970). Actions under these statutes require a showing of state action. Adickes v. S.H. Kress Co., 398 U.S. 144 (1970); Collins v. Hardyman, 341 U.S. 651 (1951). Criminal indictments are also possible under 18 U.S.C. $\$ \$ 241$, 242 (1970); they again require a showing of state action. Williams $v$. United States, 341 U.S. 97 (1951). This showing can be made by proving that state officials vere involved in the conspiracy. See Adickes v. S.H. Kress Co., supra; United States v. Guest, 383 U.S. 745 (1966); Monroe v. Pape, 365 U.S. 167 (1961).

131. Cooper v. Aaron, 358 U.S. I, 17 (1958), citing Smith v. Texas, 311 U.S. 128, 132 (1940). 